\title{
ハイブリッド車用電力貯蔵装置に関する考察
}

\section{The consideration of energy storage device for hybrid vehicle}

\section{石川哲浩*}

Tetsuhiro Ishikawa*

The number of Hybrid Vehicles, like 'Prius,' has been growing in the market worldwide in order to help decrease $\mathrm{CO}_{2}$ emissions. And Toyota Motor Corporation began leasing a new generation fuel cell vehicle the FCHV (Fuel Cell Hybrid Vehicle) in December 2002. That vehicle includes a new variable voltage power electronics system and uses the Nickel Metal Hydride (Ni-MH) battery system from the Prius hybrid gasoline electric vehicle. This paper describes on-going efforts to model optimum secondary storage systems for future vehicles. Efficiency modelling is presented for the base NiMH storage system, an ultra capacitor system and a Lithium ion ( $\mathrm{Li}$-ion) battery system. The Li-ion system in combination with a new high efficiency converter shows a $4 \%$ improvement in fuel economy relative to the base system.

KEYWORDS : Fuel-cell, Hybrid, Efficiency, Power storage device

\section{1. はじめに}

地球温暖化が問題視されている中, 二酸化炭素を発生する輸送 体である自動車の増大が㴾念されている。Fig.1に二酸化炭素の 増加の状況を示す。

その中で二酸化炭素の排出量を低減したガソリンハイブリッ ド車や二酸化炭素の排出量がない燃料電池自動車の市場への投 入がなされつつある。1997年に投入された量産ガソリン八イブ リッド車は現在では月産1万台以上が生産され, 累計のガソリン ハイブリッド車は数十万台に達している。また，二酸化炭素の排 出量がない燃料電池自動車はリース販売ながらも世界で数十台 は市場に供されている。

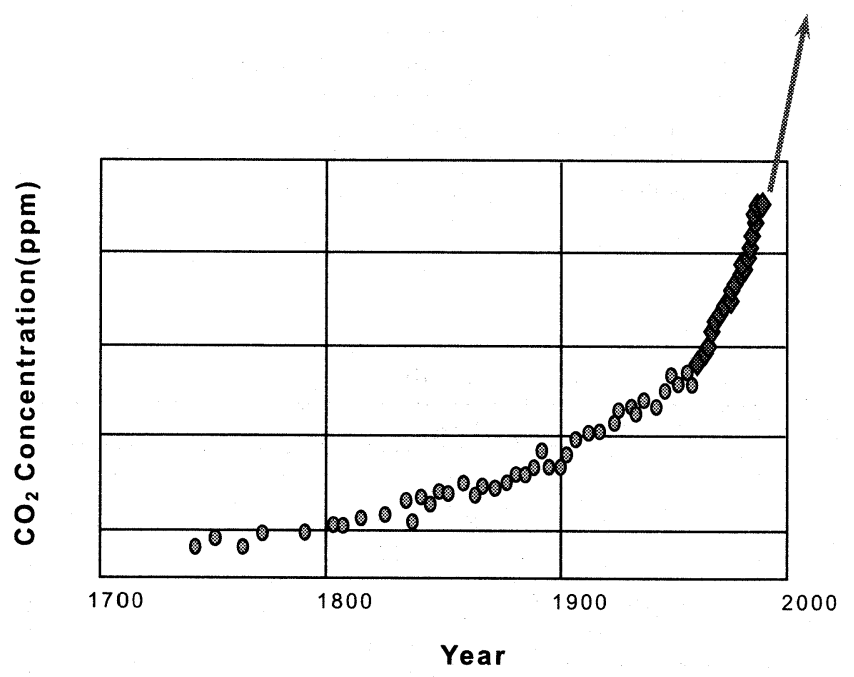

Fig.1 Condition of atmospheric $\mathrm{CO}_{2}$.

\section{2. 高効率ハイブリッド車}

このようなガソリンハイブリッド車や燃料電池ハイブリッド車 が二酸化炭素排出量低減が可能な主な理由として2点ある。そ れは, 軽負荷時の間欠運転制御と減速時の回生制動である。以下 にその2点について詳述する。

\section{1 軽負荷間欠運転制御}

車両の動力の動作点は設備のような一定点での動作というの はなくて路面状況や運転者の要求にあわせて軽負荷から高負荷 まで, 停止や低回転から高回転域まで多岐の要求が出てくる。こ のような状況下では主動力源であるガソリンエンジンや燃料電 池の動作点も要求に応じて目まぐるしく変化する。このとき効 率として重要になるのが, それぞれの主動力源の効率特性がどの ようになっているかである。

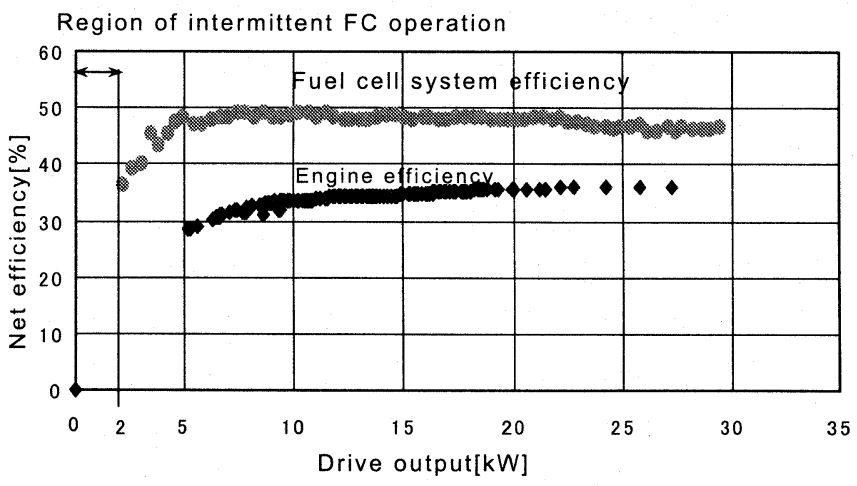

Fig.2 Comparison of net efficiency of fuel cell and engine (in Japan 10-15 Mode).

- Corresponding Author, E-mail: tetsu@ishikawa.tec.toyota.co.jp トヨタ自動車株式会社パワートレーン本部HVシステム開発部：テ471-8571 愛知県豊田市トヨ夕町 1 番地

TOYOTA MOTOR CORPORATION, Hybrid Vehicle System Engineering Div. : 1 Toyota-Cho, Toyota City, Aichi 471-8571, Japan 
ガソリンエンジンと燃料電池のネット効率を Fig.2に示す。出 力特性の軽負荷時にはともに効率が悪い。これは燃料電池にお いては, 燃料電池単体では軽負荷時には効率は向上するのだが燃 料電池の周辺機器であるエアコンプレッサーモータや燃料電池 本体の冷却用ポンプモータの消費電力があるのでネット効率と しては低下してくる1),2)。また, ガソリンエンジンでは軽負荷時 には燃焼効率の低下と冷却ポンプなどの機械損失の比率が増大 するためにネット効率としては低下してくる3)。

軽負荷間欠運転制御は,このような主動力源の軽負荷時の低効 率な領域では主動力源を停止して別の動力源で車両を駆動させ ようという制御である。ここでいう別動力源が電池などの電力 貯蔵装置である。

\section{2 回生制動}

$2 つ め の 二$ 酸化炭素排出量低減が可能な理由として車両の減速 エネルギーをモー夕を発電機として回生制動することによりエネ ルギー回収可能なことにある。同様な理由で燃料電池車も車両 の減速エネルギーを回収する機構にすることにより燃料電池機 構のネット効率が良いことにも増してさらに効率を向上させる ことが可能となる。ただ,この場合ガソリンエンジンでは可逆反 応ができないので何らかのエネルギー貯蔵装置が必要となってく る。また, 燃料電池においては, 基本的には水の電気分解は可逆 反応なので減速エネルギーは水素に戻すことは可能なのだが,この ように燃料電池の出力端に燃料電池より高い電圧を印加して逆 電流を流そうとすると燃料電池本体の膜全面に水が存在しない と燃料電池本体の寿命が低下寸ると言われている。よって, 燃料 電池車にも減速エネルギーを貯蔵する装置が必要となってくる。

\section{3 高効率ハイブリッドシステム}

前項で述べてきたように, 主動力源の軽負荷時には主動力源を 停止させて効率向上を図る軽負荷間欠運転制御や回生制動によ る減速エネルギーの回収を実現するために主動力源とは別の動 力源を加えたものが高効率を実現できるシステムである。また， その動力源はエネルギーの出し入れが可能な動力源であること は言うまでもない。世にあるエネルギー貯蔵体としては機械的 に貯蔵するものから電気化学的に貯蔵するものまで多々存在す るが, 燃料電池車を含めたハイブリッド車では車両の減速エネル ギーを回収する方法がモー夕と電力変換器であるインバー夕を 用いて機械エネルギーを電気エネルギーに変換しているので電気 化学的に貯蔵する方法が効率的にみても有利である。すなわち 電池に代表される電力貯蔵装置が適している。これらのことか ら考えると付加される動力源としては電気の形でエネルギーを 貯蔵できる形態が効率的にみても優位である。よって, 現在製作 されて世に市販されているハイブリッド車では主動力源に付加 される動力源としては電池に代表される電力貯蔵装置が大半で ある。

ただ, 電気化学的な電力貯蔵装置の中にも種々の特性をもった 貯蔵装置がある。これらの中からハイブリッドに適した貯蔵装 置を見極めることが次なる課題となるが，その見極め方としては八 イブリッドの主電源の特性を十分把握することが必要となって
くる。次項では燃料電池ハイブリッド車を例にとって燃料電池 車にとっての最適な電力貯蔵装置について述べる4)。

\section{3. 燃料電池ハイブリッド車}

\section{1 燃料電池ハイブリッドシステム}

今回検討のベースにしたトヨタ FCHV システムの概要を以下 に示す。特徵としては, 回生によるエネルギー回収を考慮して 二次電池との電源ハイブリッドにして, 二次電池は高信頼性で実 績のある Ni-MH電池を採用。また, 燃料電池と二次電池の出力 比率はモード走行の燃費を考慮して燃料電池 $90 \mathrm{~kW}$, 二次電池 $21 \mathrm{~kW}$ とした (Table 1 参照)。両電源間には使用電圧範囲を考え てブリッジ方式の昇降圧コンバータを，また，コンバータはリッ プル電流低減を目的として三相チョッパ方式を採った11。

\section{2 電源ハイブリッド構成}

燃料電池とハイブリッドにする電力貯蔵装置はどのような特 性が最適なのかを以下に示す。

\subsection{1 電力貯蔵装置}

燃料電池の特性に見合う電力貯蔵装置を見極めるために下記 2 点の観点からアプローチを行った。なお, 参考としてトヨタ FCHV と同クラスのガソリンHVとの比較も同時に行った。

(1) パワー応答性

燃料電池の出力応答性を Fig.3に示す。燃料電池の出力応答性

Table 1 System scheme of power source for Toyota FCHV.

Fuel Cell Specification

\begin{tabular}{|l|l|}
\hline Type & Polymer Electrolyte \\
\hline Fuel & Hydrogen \\
\hline Maximum Power & $90 \mathrm{~kW}$ \\
\hline
\end{tabular}

Battery Specification

\begin{tabular}{|l|l|}
\hline Type & Sealed Nickel Metal Hydride \\
\hline Capacity & $6.5 \mathrm{Ah}$ \\
\hline Cooling & Forced Air Cooling \\
\hline
\end{tabular}

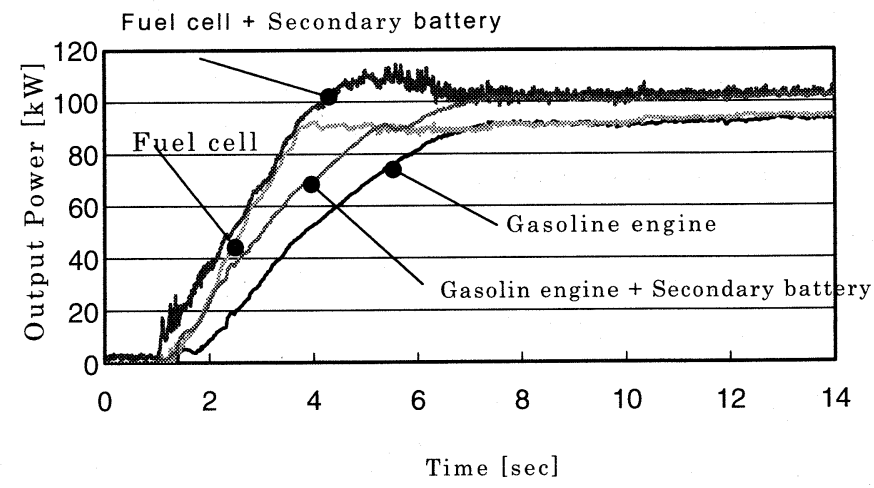

Fig.3 Fuel cell response (at WOT). 
はガソリンHVのエンジンに比べて早いので電力貯蔵装置からの 持ち出しエネルギー量は小さい。

(2) ネット効率

燃料電池システムは駆動出力の小さい領域までネット効率が ガソリン HVに比べて良いので然料電池間欠運転領域がガソリン HVのエンジン間欠運転領域に比べて狭い。よってモード走行時 ガソリン HV 車と比べると間欠時間が短く電力貯蔵装置からの充 放電量は小さくてすむ。Fig.4にLA\#4 モードを走行させたとき の電池SOC 変化量の試算結果を示す。燃料電池システムのほう がガソリンHVに比SOCの変化量が小さいのがわかる。

以上 2 点より FCHV システムとしては電力貯蔵装置に対してエ ネルギー型よりはパワー型の電力貯蔵装置が適している。

パワー型の電力貯蔵装置では, $\mathrm{Li}$ 電池, パワーキャパシタなど が現状技術では存在する (Fig.5) が, それらの各電力貯蔵装置に ついての検討結果を以下に示す。

\section{2 .2 パワーキャパシタ}

キャパシタの場合, キャパシタの仕様をいくつにするかが重要 な鍵となる。高電圧電気回路構成は, 当然キャパシタの使用電圧 範囲が広い特性を利用して Fig.6に示すようなコンバータレスの 構成が妥当である。しかし,この場合燃料電池からの出力は負荷

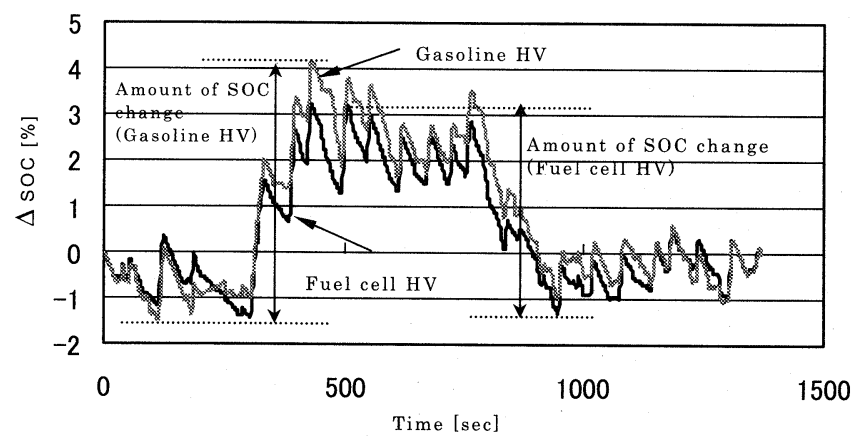

Fig.4 Amount of battery SOC change during operation in LA\#4 mode (simulation).

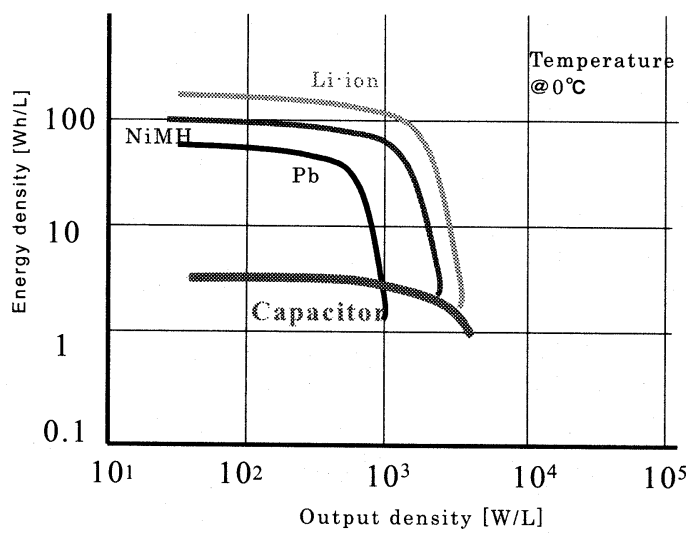

Fig.5 Ragon plot characteristics for different electrical power storage devices.
と電圧のみで決まってくるので各電源からの出力は制御できな い構成となる。

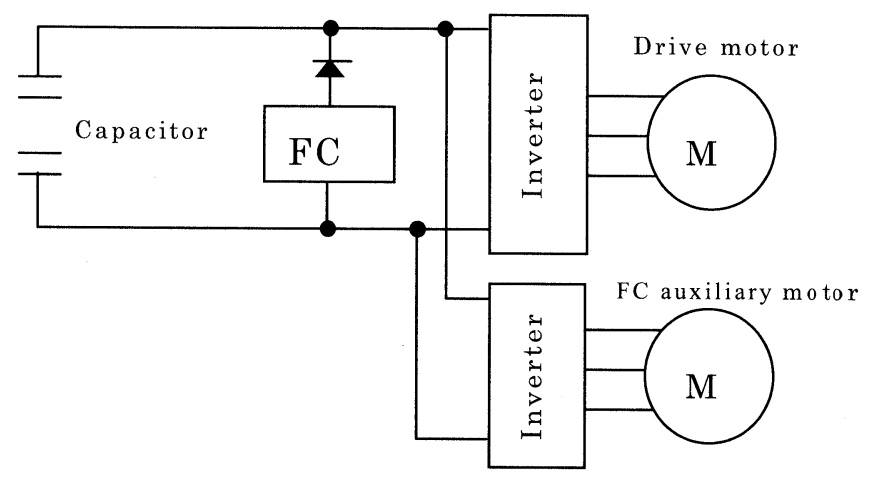

Fig.6 Capacitor system high-voltage circuit configuration.

Table 2 Specification of the system for verification.

\begin{tabular}{|l|c|}
\hline Maximum Motor output [kW] & 3.5 \\
\hline Maximum FC output [kW] & 4.28 \\
\hline FC voltage area [V] & $96-50$ \\
\hline Capacitor capacitance [F] & 39.2 \\
\hline Capacitor resistance $[\mathrm{ohm} \mathrm{F}]$ & 3.3 \\
\hline
\end{tabular}
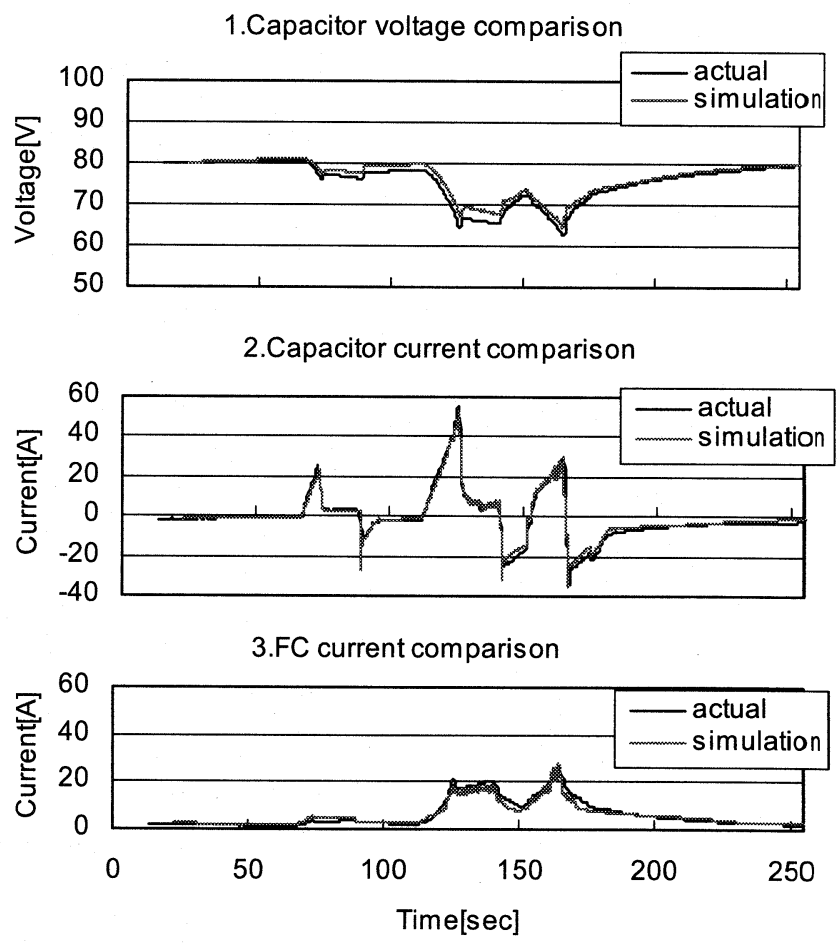

Fig.7 Congruence of simulated and actual results in mode operation. 
キャパシタの容量などの仕様の決め方として車両としての加 減速およびその繰り返し，モード走行の減速エネルギーの回収を前 提に考えなければならないが，それらを検討するシミュレーショ ンモデルの妥当性を実機評価結果との比較にて行った。モデル および実機評価は, トヨタ FCHV 実車相当をスケールダウンした もので行った。検証用システムの仕様を Table 2 に示す。また,
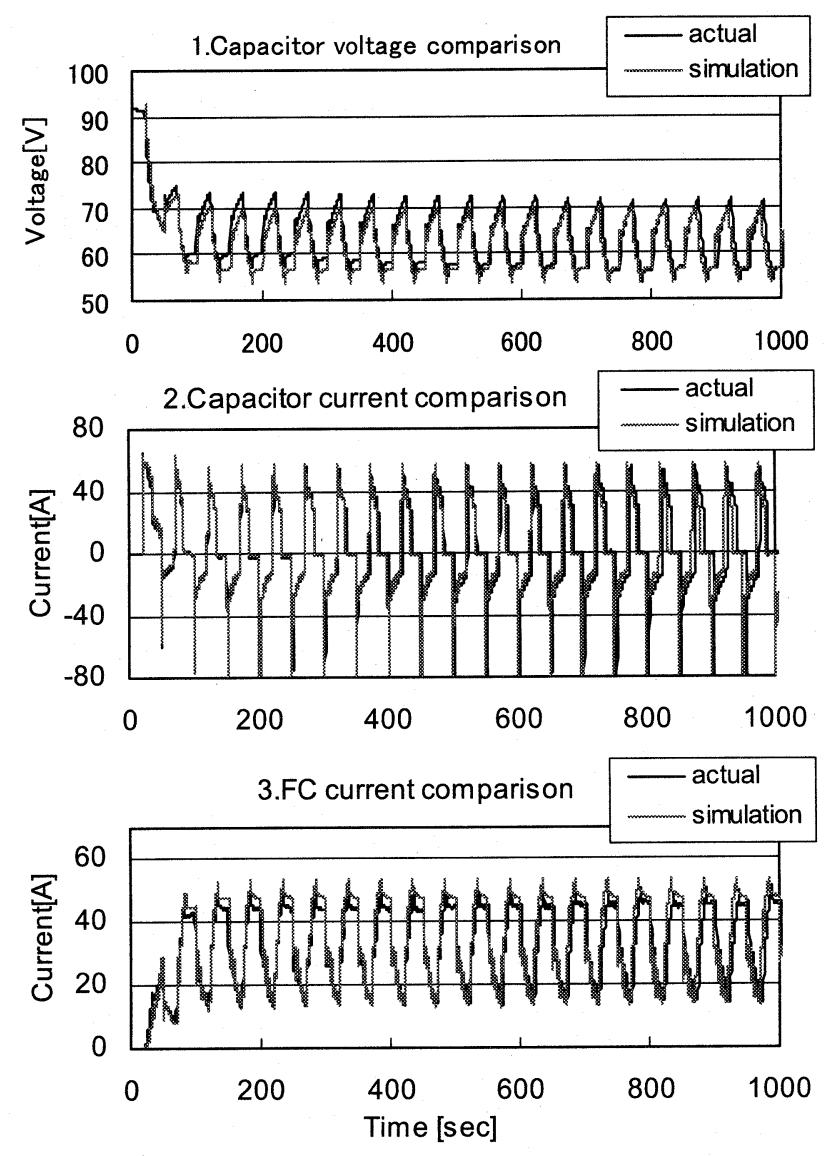

Fig.8 Congruence of simulated and actual results in acceleration and deceleration.

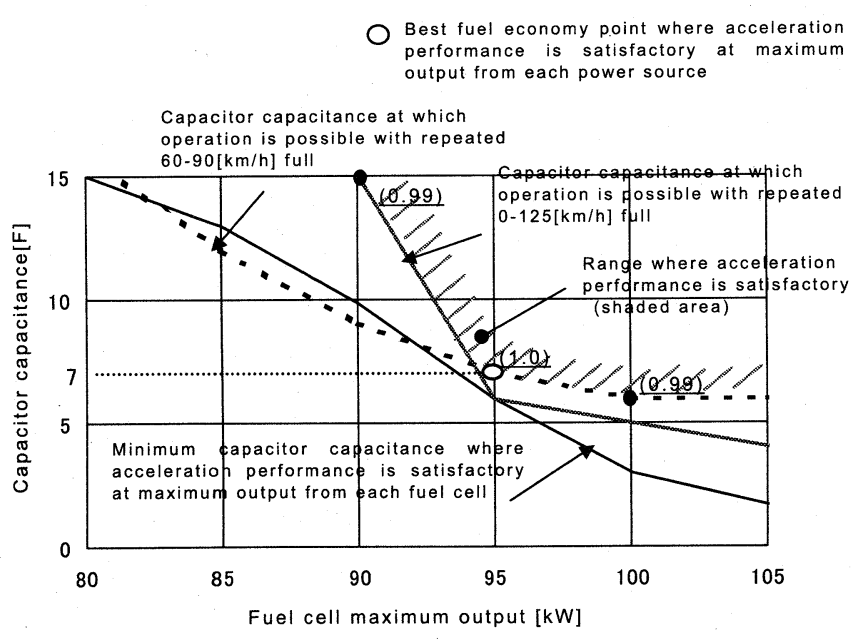

() Fuel economy index

Fig.9 Fuel cell maximum output and capacitor output.
Fig.7にはモード走行時のデータを, Fig.8には加減速を繰り返し たときの実機評価結果と試算值を示す。結果としては誤差 $3 \%$ でモデルは,ほぼ同定できている。

本モデルを用いて車両加減速などのパラメータスタディーし た結果をFig.9に示す。車両としての加速性能要求を満足しつつ, その加速の平坦路での繰り返しを行ったときにモー夕設計電圧 を下回らない限界線を示している。この図より斜線部分が所定 の要求を満足する領域となり, 然費上最も良くなるポイントは, キャパシ夕容量 $7 \mathrm{~F}$, 燃料電池最大出力 $95 \mathrm{~kW}$ である。

\subsubsection{Li 電池}

$\mathrm{Li}$ 電池を用いたシステムでの $\mathrm{Li}$ 電池と燃料電池の出力比率を パラメータとしたときの燃費特性を Fig.10に示す。Li電池出 力：燃料電池出力が $4: 6 \sim 2: 8$ が燃費上最良。よって, 燃料 電池出力を $90 \mathrm{~kW}, \mathrm{Li}$ 電池出力を $30 \mathrm{~kW}$ とする。

\section{3 燃料電池ハイブリッド高電圧システム構成}

前項で検討してきた燃料電池に適したハイブリッド電源のそ れぞれに対しての高電圧電気システム回路構成を以下に示す。

\subsection{1 パワーキャパシタシステム}

先に述べたようにパワーキャパシタを用いた場合にはパワーキ ヤパシタの使用電圧範囲の広さを利用して燃料電池とは並列接 続とした高電圧電気システム構成とする。

\subsubsection{Li電池システム}

$\mathrm{Li}$ 電池を電力貯蔵装置に用いた場合, 使用電圧範囲が限定され るのでコンバータが必要となってくる。しかし, Li電池は高パワー 密度であるのでコンバー夕回路構成をブリッジタイプから効率の 良いハーフブリッジタイプに変更可能となる。その状況を Fig.11 に示す。ハーフブリッジ化には燃料電池の使用電圧範囲と Li 電 池使用電圧範囲を離すことが必要となるが電池モジュール数を 60 モジュール以下にすれば可能となる。また, 変圧比が上昇する ことによるコンバータ損失増大を考慮してもブリッジタイプより ハーフブリッジタイプの方が良いことがわかる。

\subsection{3 燃費特性}

前項で述べた高電圧システム構成での燃費比較を Table 3 に示 す。現行システムの Ni-MH システムに対して Li電池システムが

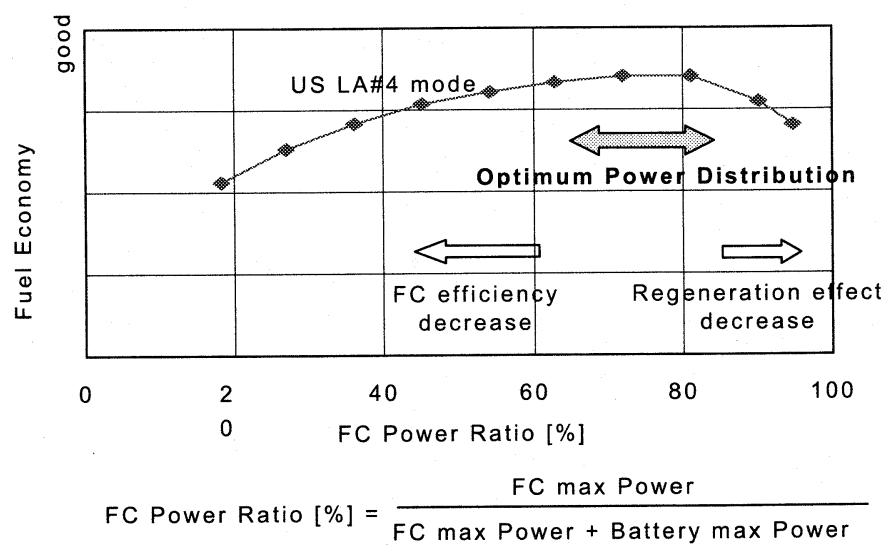

Fig.10 Fuel Cell maximum output and Li-ion battery output. 


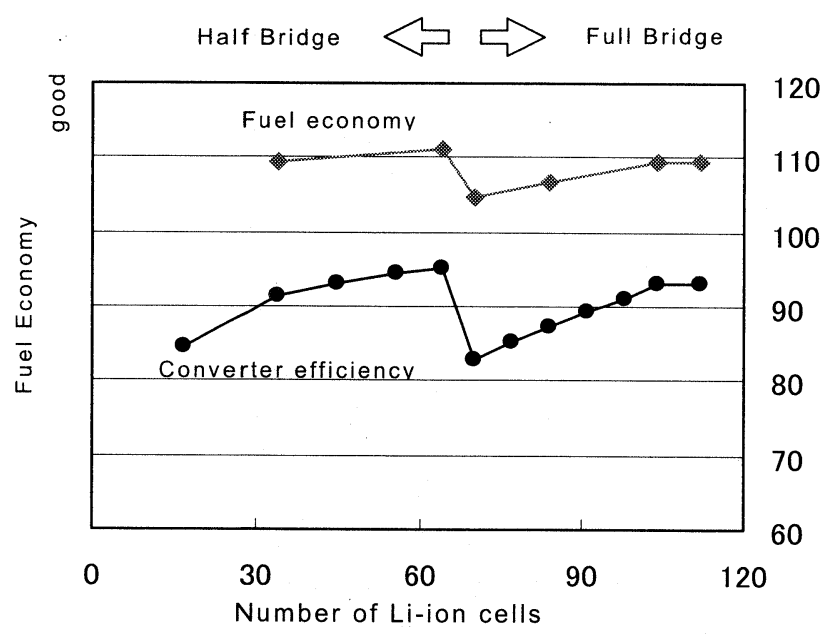

Fig.11 Efficiency of Li-ion system.

Table 3 Comparison of fuel economy in LA\#4 mode.

\begin{tabular}{|l|c|c|c|}
\hline & Capacitor & Ni-MH & Li-ion \\
\hline $\begin{array}{l}\text { Volume [L] } \\
\text { (with converter } \\
\text { \& FC stack) }\end{array}$ & 235 & 220 & 196 \\
\hline $\begin{array}{l}\text { Weight [kg] } \\
\text { with converter } \\
\text { \& FC stack) }\end{array}$ & 259 & 252 & 206 \\
\hline $\begin{array}{l}\text { Fuel economy index } \\
\text { (Ni-MH=100) }\end{array}$ & 93.7 & 100 & 104.2 \\
\hline $\begin{array}{l}\text { Fuel economy } \\
\text { Improvement [\%] }\end{array}$ & 11.3 & 4.2 & $\longrightarrow$ UP \\
\hline
\end{tabular}

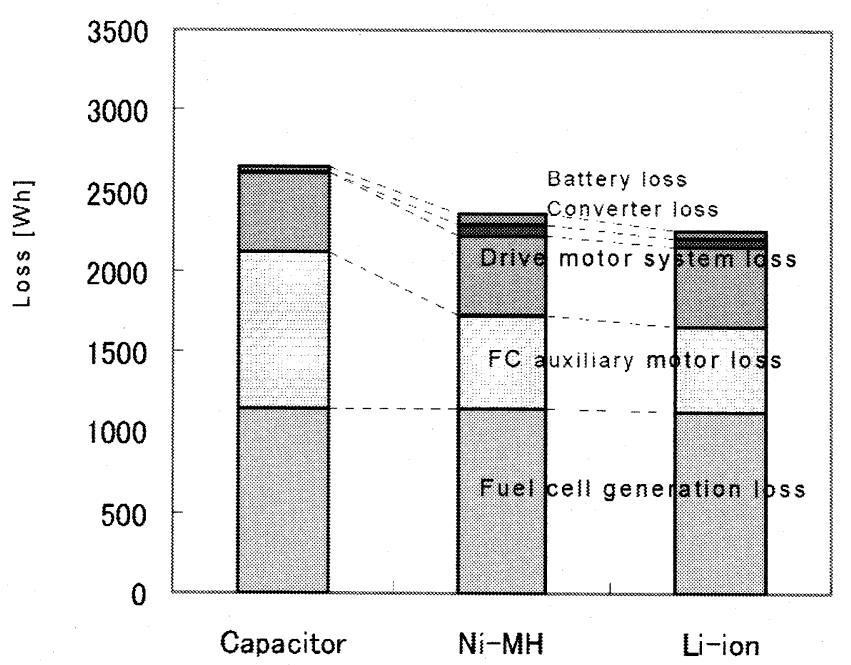

Fig.12 Comparison of loss in different systems.

燃費上最も良く, 現行システムに対して約 $4 \%$ の燃費向上が可能。 パワーキャパシタシステムは燃料電池の間欠運転ができないので

Fig.12に示すように補機損失が増大して燃費は現行システムよ
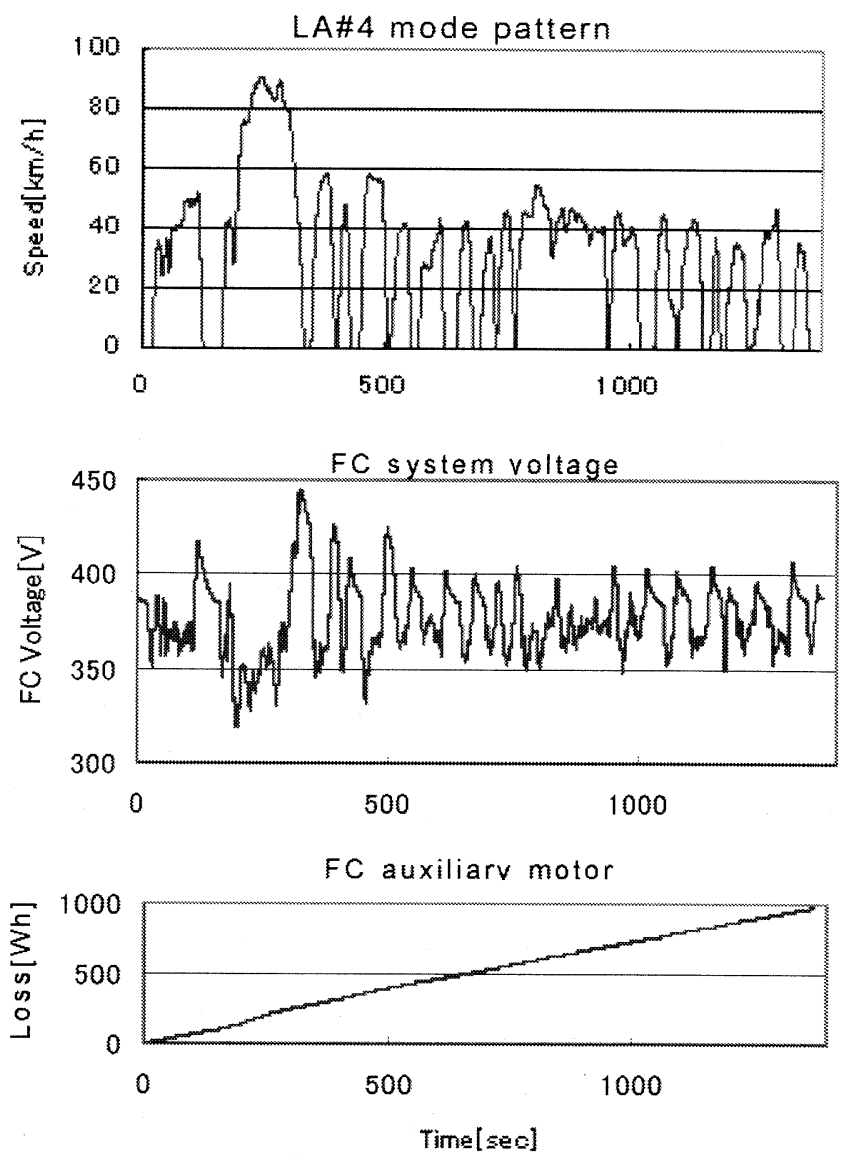

Fig.13 Voltage and power transitions in capacitor system.

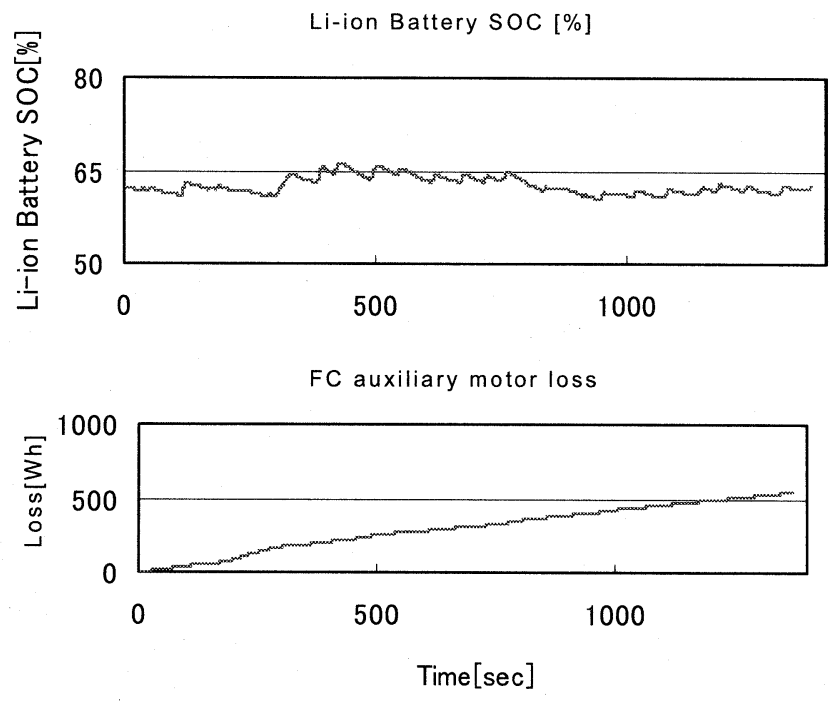

Fig.14 SOC and loss transitions in Li-ion battery system.

\section{り悪化する。}

各システムでのモード走行時の各部位の損失推移と電圧, SOC の変化状況を Figs.13, 14 に示す。コンバー夕を用いている Ni$\mathrm{MH}$ や Li電池システムでは車両停車時および減速による回生時 には燃料電池間欠運転が可能となり燃費がよい。 


\section{4 まとめ}

（1）燃料電池システムの特性を踏まえた最適電力貯蔵装置であ る Li電池と高効率なハーフブリッジ式コンバー夕回路を採 用した高効率な次世代FCHV 高電圧システムを導き出した。

（2）本システムでは二次電池の軽量化およびコンバー夕損失低 減により燃費を現状のトヨタFCHVより約 4 \% 向上させるこ とが可能。

（3）パワーキャパシタを用いたシステムでは燃料電池の間欠運 転ができないために然費はLi電池を用いたシステムより $11 \%$ 劣ることがわかった。

\section{4. ハイブリッド車用電力貯蔵装置に関する考察まとめ}

以上燃料電池車のハイブリッド用電力貯蔵について詳細検討 内容を述べてきたが, 重要なことは車両からの要求特性とハイブ リッドにすべく主電源および電力貯蔵装置の特性を踏まえて最 適な貯蔵装置を選択しなければならないということである。特
に電力貯蔵装置の技術進歩は目を見張るものがあるので, その技 術進歩に応じて最適システム構成は変わる可能性がある。現在 の貯蔵装置を踏まえたシステム構成が未来永劫最適とは限らな いということでもある。

\section{文 献}

1) T. Matsumoto, N. Watanabe, H. Sugiura and T. Ishikawa, "Development of Fuel-cell Hybrid Vehicle", the 2002 SAE World Congress (2002).

2) Y. Hori, T. Teratani and R. Masaki, "Motor Technology for Automobile", The Nikkan Kogyo Shimbun, LTD (The Business \& Technology Daily News) (2003).

3) S. Sasaki, T. Takaoka, H. Matsui and T. Kotani, "Toyota's Newly Developed Electric-Gasoline Engine Hybrid Power train System", The $14^{\text {th }}$ International Electric Vehicle Symposium (1997).

4) T. Ishikawa, S. Hamaguchi, T. Shimizu, T. Yano, S. Sasaki, K. Kato, M. Ando and H. Yoshida, "Development of Next Generation Fuel-cell Hybrid System", the 2004 SAE World Congress (2004). 